\title{
The Pedagogy of Engagement: A study of architecture students' learning experience in community partnership
}

\author{
$\left[{ }^{* 1}\right.$ TamilSalvi Mari, ${ }^{* 2}$ Sivaraman Kuppusamy, ${ }^{* 3}$ Sucharita Sriangam and ${ }^{* 4} \mathrm{Ng}$ Foong Peng] \\ ${ }^{*} 1, * 3, * 4$ Taylors's University, Lakeside Campus, \\ Petaling Jaya, Selangor, Malaysia. \\ ${ }^{* 2}$ University of Reading Malaysia, Iskandar Puteri, \\ Johor Darul Takzim, Malaysia.
}

\begin{abstract}
Architecture education, have not changed over years, and this would be its greatest fear. Current teaching pedagogies in architecture education have been criticized by academia, industry and public as the graduates are unable to meet the society and industry demands. Architecture instructors often pay more attention to physical models and drawing produced by students rather than the students' experience of real life engagements with external communities. Moreover, the students hardly experience the real life projects thus their learning experiences are limited. Various literatures have reported on students' enhanced learning experiences in academic service-learning projects with real community partnerships. However, there are fewer published studies on architecture students' learning experience using servicelearning. Therefore, this study addresses the gap in the literatures as it examines the architecture students' learning experience using the service-learning pedagogy in forming community partnerships while achieving the academic learning outcomes. The study uses a quantitative method of descriptive approach with survey design. Collected data is analyzed using Descriptive and Inferential statistics. The respondents for this study were year two (2) and year three (3) architecture students from two (2) private higher education institutions in Klang Valley, to offer a variety of perspectives. The respondents included students who have taken modules with service-learning projects and those who have taken the same module without the service-learning projects. Findings from the study showed that the total mean score for service learners is higher $(\mathrm{M}=3.75, \mathrm{SD}=0.87)$ compared to non-service learners $(M=1.21, S D=0.47)$. Further analysis revealed a moderate positive strength of relationship and significance enhancement of learning experience for service learners while the findings for non-service learners revealed a very weak positive strength and non-significance in enhancement learning experience. Therefore, the study suggest that service-learning pedagogy enhances students' learning experiences and nurtures commitment towards community.
\end{abstract}

Learning experience; architecture; service-learning; community; partnership

\section{Introduction}

Current teaching pedagogies in architecture education have been criticized by academia, industry and public as the graduates are unable to meet the society and industry demands. Colomina [1] commented that, current architectural pedagogy has become stale. In elaborating the comment, the author [1] stated that architecture instructors are engaged in outdated teaching pedagogies and as a result, the teaching approaches and assessments are the unchanged all these years. This form of teaching and learning deprives students of innovative engagements with the real world and affects the development of valuable skills and competencies that are vital for their employment in the future. Till [2] asserted that architectural education, its fundamental procedures and processes have not changed over years, and this would be its greatest fear and urged for the need for transformation in the structure and values of architecture education. In present day teaching, architecture instructors often pay more attention to physical models and drawing produced by students rather than the students' experience of real life engagements with the external community. A report by RIBA [3] stated that architecture schools are struggling to keep up with the recent issues that are transforming architecture practice and students are not educated to meet the industry and wider market needs.

In architectural education conventional teaching approaches often emphasizes learning contents and teamwork among students. These approaches do not clearly describe, learning experience and generally limits the type of learning to that of identifying or remembering facts, procedures, and theories. Past studies on teaching pedagogies have shown that students' learning experience can be enhanced adopting a more engaging and dynamic teaching pedagogies for instance, the service-learning (SL) pedagogy. Learning experience can be explained any collaboration, course, or other experience in which learning takes place, whether it take place in traditional academic settings such as classrooms or non-conventional settings outside-of-classroom. Morgan and Beatty [4] explained that "learning experience' is seen as a relationship that occurs between a course and a student, it is neither a feature of the course itself nor attribute or personality characteristic of the student, but rather the dynamic experience between the student and the course. Alternatively, by adopting SL as teaching pedagogy, the learning content can be taught more broadly and effectively to the architecture students. Salama [5] described learning content as collections of teaching models and resources that contribute in shaping a student's learning experience that are aligned with learning outcomes and positive actions that stem from the experience.

According to Cashman and Seifer [6] in SL projects learners apply what they are learnt in the classroom to solve the community issues, and at the same time reflect on their experiences to achieve specific objectives. SL as an 
Proc. of The Seventh Intl. Conf. on Advances in Social Science, Management and Human Behaviour - SMHB 2018.

Copyright (C) Institute of Research Engineers and Doctors, USA. All rights reserved.

ISBN: 978-1-63248-160-3 doi: 10.15224/978-1-63248-160-3-21

engaging pedagogy not only enhances students' learning experience with outdoor hands-on activities but also valuable opportunity to identify and understand external community problems from a different perspective. 'External community' refers to those specific, local, mutual interest groups that works together with the students to solve or to find a solution for real life issues of the community. This external community is regarded as partners or recipient, who works with the students in identifying the issues and needs of the community. They also participate in defining the SL outcomes, identify the relevant resources, evaluate the impact, and contribute towards finding the solutions. This engaging pedagogy provides a challenging and exciting learning experience with the whole learning content and process set in the real world setting, thus increases students' self-confidence in applying their knowledge and skills in the real world.

Nicol \& Pilling [7] commented that architecture is a participative process, but the teaching and learning in architecture design studio is often secluded from the real world and from the kinds of interactions and collaborations that would occur in the practice. The practice of architecture requires designers to solve real issues working with the community and for the community, but the current teaching and learning in architecture education does not reflect the actual practice. It lacks real life experience and the emphasis on engagement and importance of service within the community. By adopting SL pedagogy the issues can resolved, and in addition, it can contribute towards enhanced learning experience in students. In architectural programmes using SL pedagogy is an educational experience in which students involve in a prearranged service base activity that identify and solve community needs. According to some reported studies, faculty who practiced service-learning learnt that it made the classroom environment to livelier, enhanced performance on traditional measures of learning, enhanced students' interest in the subject, enhanced development of problem solving skills, and made teaching and learning more enjoyable. McEwen [8] opined that SL is an educationally and socially influential intervention that has a great potential for enhancing learning and development of college students. Real architectural practice in the total community includes architectural and international knowledge joint with inter cross-cultural competencies leading to informed judgements about the built environment [9].

The Boyer Report [10] on architectural education contained within the recommendations the need to provide a wider range of experiences to the architecture students, states "The curricula and design orders at architecture schools should... [include] more frequent interaction with clients and communities by introducing more importance on 'environment-behaviour' studies". The report recommended a connected curriculum would encourage the integration, application and discovery of knowledge within and outside the architecture discipline, while effectively making the connections between architectural knowledge and the changing needs of profession, clients, communities and society as a whole". The report suggested SL pedagogy to address the concern to ensure community engagement experience in architectural education. While, Brazley and Brazley [11] opined that SL is the present state of design pedagogy in architecture education, with reference to the book by Boyer and Mitgang [12] entitled "Building Community: A New Future for Architecture Education and Practice" which outlines the role of architecture education in engaging with the community and addressing to the real concerns of our society. The authors [11] argued that architectural education lacked a sense of purpose in linking the profession to the present problems of society.

The architectural practice in Malaysia has supported the use of real life projects in architecture schools. SL uses real life projects, therefore exposing students to real issues that requires logical solutions that are more enticing for students to work and reflect upon. These projects usually includes interaction with real clients, engagement with real external communities, or building users. Bringle, Hatcher and McIntosh [13] described SL as credit-bearing educational experience in which students participate in an prearranged service activity for certain community and their reflection on the service activity that enhances their understanding of course content, a wider appreciation of the profession, and sense civic responsibilities. However, most of the architecture schools continues to side-line SL based community projects with academic outcomes. At present, there are limited published studies investigating architecture students' learning experience using service-learning pedagogy. Therefore, this study addresses the gap in the literature as it examines the architecture students' learning experiences using the SL activities while forming partnership with community while achieving the academic goals.

\section{Literature Review}

SL is a form of experiential education that engages learners more fully in the learning process [14]. According to Prentice and Robinson [15] SL is a teaching methodology, which provides opportunity for students to develop as both citizens and scholars who have the knowledge and commitment to serve an increasingly complex society. There are diverse definitions for SL nevertheless, the main essence of SL is the "service and learning" that happens in experiences of reflection and civic engagement within a partnership with external community. Reciprocity is the core value of service-learning pedagogy whereby both the students and community will benefit at the end to the service project. Clinton and Thomas [16] carried out a study to explore university students' experience of SL in the community and to examine the attributes students acquired from their partnership experience. Results of the study revealed that students had developed understanding of other peoples' situation and felt as part of the society they should do more and the students reported that they realized that their contribution could make others happy. In another documented study, a group of architecture students participated in public project in Haiti that used SL pedagogy during the summer design studio. Students who participated in the project reported that they were able to produce better design solutions working with the locals as the locals worked with them to provide them with the information 
Proc. of The Seventh Intl. Conf. on Advances in Social Science, Management and Human Behaviour - SMHB 2018.

Copyright (C) Institute of Research Engineers and Doctors, USA. All rights reserved.

ISBN: 978-1-63248-160-3 doi: 10.15224/978-1-63248-160-3-21

necessary for their design solution based on their experience on the use of the spaces [17].

The study by Clinton and Thomas [16] also reported that one quarter of the students gained an awareness of the spirit of community service, one of the students reported that he learnt a lot of from the service experience and it has been a very momentous experience for him. Another student in the study reported that the service affected his attitudes and values; he indeed enjoyed his time at the community centre. The found that students have learnt a lot pertaining to the community's issues and needs and valued the opportunity to work with many inspiring people. Brazely and Brazely [11] conducted a study to examine the outcome of architecture studio in the post-Katrina reconstruction of the Lower 9th Ward community. The design studio adopted SL activities where students performed community service. Results of the study elucidated that most of the students developed better understanding of the urban design and sustainability. The study reported that the students were of the opinion that architecture should act as an advocate for underrepresented communities, and acknowledged that there was value in the partnership between the studio and the community. Malkawi [18] postulated that service-learning for architecture students help them in developing skills in decision making, problemsolving, team building, critical analysis, and to build new partnerships between community and school that fostered students achievement. Jacobs and Archie [19], described SL as experiential education, both as a methodology and philosophy, is appropriate as it has potential to have a positive effect on a learner's sense of "community". Prentice and Robinson [15] conducted a study on community colleges students involved in SL activities. The study explored community engagement and reported that students have a commitment to continue to be involved within their communities. Gallini \& Moeley [20] based on results of study stated that service-learning students scored significantly higher on measures of interpersonal, academic, and community engagement. A study by Buch and Harden [21] found that students had a greater awareness of the needs of the homeless in their community. Fudge, Burton, McClam and Diambra [22] also reported that students having a greater awareness of needs of the people that they worked with as part of the SL activities. Krebs [23] conducted a study exploring the incorporation of SL among K-12 teachers. Participants in this study reported that SL broadened the students' awareness of community needs. An earlier study by Wittmer [24] found that $48 \%$ of the students who participated in SL at the University of Denver in an ethics-based MBA core course called 'Values-Based Leadership" reported SL activities enhanced their learning experiences, as their ability to identify the level and type of community needs increased. The learning experienced by students by incorporating SL pedagogy in architecture education is not only enhanced but the SL strategy primarily emphasizes on how students engage the communities. Brazley and Brazley [11] advocated SL as design pedagogy, as the architecture students are interested in learning and serving the community, particularly if both can be achieved at the same time:

\section{A. Objective of the Study}

The purpose of this study is to examine students' learning experiences in modules that had incorporated service-learning pedagogy in undergraduate architecture education. The main objective of this study is to determine the relationship between students' experience of community partnership and SL pedagogy in architecture education..

\section{B. Significance of the Study}

The outcomes of this study will be used to improve the quality of teaching and learning which can be evidenced in the student learning outcomes in architectural education in context of the architecture degree Part I. The findings from this study adds to a growing body of research on the concept and practice of SL in architectural education. The study identifies the strengths and limitations of SL pedagogy when incorporated in architectural education. The findings also will support the inclusion of SL pedagogy as one of the main teaching pedagogies in undergraduate architecture education. The study provides data and valuable information pertaining to the students' learning experience forming partnership with external community thus enlightening past researches. Additionally, the study provides better understanding for schools into how serving the community needs can contribute to the development of student attributes. Furthermore, students who were exposed to SL benefited from enhanced learning experiences by understanding and exploring real solutions for issues or needs of external communities thus, supporting the incorporation of service-learning pedagogy in the undergraduate architecture education.

\section{Methodology}

The study used a quantitative method of descriptive approach using the survey design [25]. The respondents for this study comes from two (2) private higher education institutions in Klang Valley, Higher Education Institution 1 and 2 (HEI 1 and HEI 2) to offer a variety of perspectives. The respondents were year two (2) and year three (3) undergraduate architecture students including those who have taken the module with SL projects and those who have taken the same module without the SL projects. The total number of respondents for the study was 215 . The student survey instrument contained questions in a 5-point Likertstyle scale where the number " 5 " indicated the highest response and " 1 " indicated the lowest response. Descriptive analysis was used to analyze the data using frequency, mean, scores and standard deviations of independent variable and dependent variable in SPSS v. 20. Pearson's correlation analysis was conducted to determine the relationship between students' learning experience and SL pedagogy. Regression analysis was used to identify the significance in the relationship between students' learning experience and SL pedagogy. Regression analysis indicates the relative strength of learning experiences (IV) effects on SL pedagogy (DV) and was used in making the predictions

\section{Findings}

Examination of Table 1 below shows the total mean score for service learners is higher $(M=3.75, S D=0.87)$ compared to non-service learners $(M=1.21, S D=0.47)$. 
Proc. of The Seventh Intl. Conf. on Advances in Social Science, Management and Human Behaviour - SMHB 2018.

Copyright (C) Institute of Research Engineers and Doctors, USA. All rights reserved.

ISBN: 978-1-63248-160-3 doi: 10.15224/978-1-63248-160-3-21

This suggests that in service-learning projects with real life community engagements students are able to experience working with people and understanding their needs. The score by non-service learners is not surprising as most modules in architecture allows only for minimal contact or engagement with community unlike modules with servicelearning pedagogy.

TABLE 1: DESCRIPTIVE STATISTICS FOR STUDENTS' LEARNING EXPERIENCE

\begin{tabular}{|c|c|c|c|c|c|}
\hline & \multirow{2}{*}{$\begin{array}{l}\text { Learning Experiences with } \\
\text { Community Partnership }\end{array}$} & \multicolumn{2}{|c|}{ Service learner } & \multicolumn{2}{|c|}{$\begin{array}{c}\text { Non-service } \\
\text { learner }\end{array}$} \\
\hline & & Mean & $S D$. & Mean & $S D$. \\
\hline LE1 & $\begin{array}{lcr}\text { I managed } & \text { the } & \text { module } \\
\text { workload } & \text { with } & \text { good } \\
\text { cooperation } & \text { from } & \text { the } \\
\text { community } & & \end{array}$ & 3.87 & 0.772 & 1.22 & 0.415 \\
\hline LE2 & $\begin{array}{l}\text { I completed community } \\
\text { related task within given } \\
\text { time as the organization was } \\
\text { understanding of my } \\
\text { commitment as a student }\end{array}$ & 3.99 & 0.778 & 1.35 & 0.627 \\
\hline LE3 & $\begin{array}{l}\text { I managed to get the needed } \\
\text { information promptly from } \\
\text { the com. organization I } \\
\text { worked with. }\end{array}$ & 3.61 & 0.856 & 1.16 & 0.418 \\
\hline LE4 & $\begin{array}{l}\text { I am keen to be involved in } \\
\text { community service in the } \\
\text { future. }\end{array}$ & 3.50 & 1.002 & 1.16 & 0.464 \\
\hline LE5 & $\begin{array}{l}\text { I can now connect my } \\
\text { learning to my professional } \\
\text { commitment to community }\end{array}$ & 3.48 & 0.996 & 1.18 & 0.385 \\
\hline LE6 & $\begin{array}{l}\text { The community assisted in } \\
\text { understanding their issues } \\
\text { and needs }\end{array}$ & 4.02 & 0.812 & 1.18 & 0.518 \\
\hline
\end{tabular}

Among the six (6) items measured, the score for item no. LE6 - The community assisted in understanding their issues and needs was scored the highest with a mean of 4.02 ( $S D=$ $0.812)$. Service learners also reported a high mean score $(M$ $=3.99, S D=0.778)$ for item LE2 - I completed community related task within given time as the community understood my commitment as a student. Both these scores suggest that service learners learnt to engage and form a partnership with external community organization. This was followed by the mean score for item LE1- I managed the module workload with good cooperation from the community. Result for this item explains that the external communities understand their role in students learning. The score for items LE3, LE4 and LE5 are generally at the medium level, and the lowest mean score $(M=3.48, S D=0.996)$ is for item LE5 - I can connect my learning to my professional commitment to community.

Pearson's $r$ data analysis revealed a moderate correlation occurred between students' learning experience $(M=3.75$, $S D=0.655)$ and service-learning pedagogy $(M=3.99, S D=$ $0.545)$. The analysis revealed a moderate positive strength and significantly correlated, $r(112)=0.589, p=0.001$. This shows that the students' learning experiences are enhanced when SL pedagogy is used in architecture education. Regression analysis for the study, with learning experience as the independent variable (IV) and SL pedagogy as the dependent variable (DV) shows a significant relationship (pvalue of 0.001 ) between the IV and DV. The calculated $R^{2}$ for the regression equation is 0.343 . This indicates the strength of relationship, meaning students learning experience explains $34.3 \%$ of the variance in SL pedagogy. The ANOVA analysis shows that students' learning experience with community partnerships is a significant predictor of SL pedagogy, $F(1,162)=16.774, p=0.001, R^{2}=$ 0.343. The F-statistic value of 86.075 indicated the significance of the regression model. The unstandardized $\beta$ coefficient of 2.157 indicates the degree to which the learning experience (LE) predicts the impact of SL pedagogy, meaning for every unit of increase in learning experience a 2.157 of unit increase in SL is predicted. Students' learning experience forming partnership with communities, is a significant predictor of SL pedagogy (SL), $\beta=2.157, \quad p=0.000, R^{2}=0.343$. The regression analysis can be explained as $\mathrm{SL}=2.157+0.489(\mathrm{LE})$

\section{v. Discussion and Conclusion}

The descriptive analysis elucidated a high mean score for service learners and a very low mean score for non-service learners. Service learners identified that they are keen to be involved in community service after graduation as the highest score this concurs with findings by Clinton and Thomas [16]. Following this, they reported that they were able to complete the academic task on time with the support of community partners who provided the necessary information and resources related to the task, this results is the same the reported in [17]. Further analysis, revealed a moderate positive strength of relationship and significance in students' learning experience for service learners whilst the analysis for non-service learners revealed a very weak positive strength with service-learning pedagogy and nonsignificance in enhancement learning experience. This study result concurred with earlier studies [11], [16], and [18] that suggested using SL pedagogy has shown significant enhancement in students' learning experience.

In this study, service learners scored high in rating the learning experience using the SL pedagogy in forming community partnerships. The findings shows a moderate strength of relationship between students' learning experience and the service-learning pedagogy. Therefore, this study suggests that incorporating SL into architecture education has significant impact on community awareness and commitments

Findings also show that service learners managed their assigned task with good cooperation and support from the external communities. The study found that community partners recognized the value of relationship in encouraging community participation mainly service activities involving students. Agreeing to the findings by Prentice and Robinson [20], service learners also reported that they are keen to be involved in community service after graduation. Service learners also identified working with external communities them the opportunity to understand real world issues. This supports the perception that SL activities with community engagement create awareness of the needs of the community in students. The result corresponds with past studies of SL pedagogy outcomes by [20] - [23] that reported that students developed greater awareness of needs of the people they worked with as part of the service-learning activities. 
Proc. of The Seventh Intl. Conf. on Advances in Social Science, Management and Human Behaviour - SMHB 2018. Copyright (C) Institute of Research Engineers and Doctors, USA. All rights reserved.

ISBN: 978-1-63248-160-3 doi: 10.15224/978-1-63248-160-3-21

SL pedagogy greatly affects students' learning experience forming partnership with external community. External community partners and students discovered how to complement and support each other to gain mutual benefit and students' academic success. This study results also corresponded with earlier study by Wittmer [24] at the University of Denver where the SL students reported that their learning experience working with community increased their ability to identify the diverse needs of the community. The study suggests that SL pedagogy nurtures commitment in students towards community involvement and at the same time enhances students' learning experience. Architecture is naturally a social practice and the students by working in partnership with a community organization, learn how to identify nonmaterial values to serve as basis for collective project definitions and goals.

The study examined the use of SL pedagogy in undergraduate architecture modules and its relationship with students' learning experience. The study result shows that students' learning experiences are enhanced when SL is used as the teaching pedagogy. The study findings also corresponds with past studies that investigated the use of SL pedagogy and students' learning experience. Vlahos [26] opined that architecture students involved in a community design project gained knowledge of the design process, an exploration of how culture informs the design process, an understanding of the community needs and assets, experience working with a community of economic and cultural diversity, and an understanding of the obstacles often encountered in "real life" projects. Based on the findings the study suggest that service-learning pedagogy enhances students' learning experiences and nurtures commitment towards community. Therefore, the study suggests that service-learning pedagogy is suited for undergraduate architecture education teaching.

\section{References}

[1] B. Colomina, "Radical pedagogies in architectural education", The Architectural Review: The Education Issue, 2012.

[2] J. Till, "How will architects be educated in 20 years' time. The Future of Architectural Education." Building Futures Think Series. 2012.

[3] Royal Institute of British Architects (RIBA). "RIBA constructive change: A strategic industry study into the future of the architects' profession", London, UK, 2005.

[4] A. Morgan and L. Beatty, "The world of learner", in The Experience of Learning: Implications for teaching and studying in higher education, 3rd ed., F. Marton, D. Hounsell and N. Entwistle, Ed. Edinburgh: University of Edinburgh, Centre for Teaching, Learning and Assessment., 2018, pp. 217-237.

[5] A. Salama, "Beyond the consumption of knowledge: questioning of and questing for future forms of pedagogy in architectural education", 2012. [Online]. Available:

http://www.academia.edu/3205216/Beyond_the_Consu mption_of_Knowledge_Questioning_of_and_Questing for_Future_Forms_of_Pedagogy_in_Architectural_Edu cation. [Accessed: 05-Feb-2016].

[6] S. Cashman and S. Seifer, "Service-learning: An integral part of undergraduate public health." American Journal of Preventive Medicine, vol. 35, no. 3, pp. 273278, 2018.
[7] D. Nicol and S. Piling, Changing architectural education. London: E \& FN SPON, 2005.

[8] M. McEwen, "Enhancing student learning and development through service-learning", in Servicelearning in higher education: Concepts and practices, 1 st ed., B. Jacoby, (Ed.). San Francisco, CA: JosseyBass Publishers, 1996, pp. 217-237.

[9] K. Beaverford, "A global perspective on architectural education", in IASDR 07, Hong Kong, 2007, pp. 1-11.

[10] AIA Knowledge Resources Staff, "The Boyer Report. (Adapted from the Boyer Report Revised December 2006)", Boston, 2006.

[11]M. Brazley and M. Brazley, "What is the future and vision of architectural education?" The IUP Journal of Architecture, vol. 3, no. 1, pp. 75-109, 2011.

[12]E. Boyer and L. Mitgang, "Building community: A new future for architecture and practice." The Carnegie Foundation for the Advancement of Teaching., New Jersey, 1996.

[13]R. Bringle, J. Hatcher and R. McIntosh, "Analyzing Morton's Typology of Service Paradigms and Integrity", Michigan Journal of Community Service Learning, vol. 13, no. 1, pp. 5-15, 2006.

[14]M. Prentice and R. Garcia, "Service-learning: The next generation in education", Community College Journal of Research and Practice, vol. 24, no. 1, pp. 19-26, 2000.

[15]M. Prentice and G. Robinson, "Linking service learning and civic engagement in community college students", American Association of Community College, Washington, DC, 2007.

[16]I. Clinton and T. Thomas, "Business students' experience of community service learning.", AsiaPacific Journal of Cooperative Education, vol. 12, no. 1, pp. 51-66, 2011.

[17] The 2014 Haiti summer studio, "Evaluation of learning and outcomes from the 2014 Haiti summer studio", 2014.

[18]A. Malkawi, "Serving the community through "service learning, approach: A case of integration", in ACSA International Conference., Rome, 1999, pp. 123-125.

[19] J. Jacobs and T. Archie, "Investigating sense of community in first-year college students", Journal of
Experiential Education, vol. 30, no. 3, pp. 282-285, 2008.

[20]S. Gallini and B. Moely, "Service-learning and engagement, academic challenge, and retention." Michigan Journal of Community Service Learning, vol. 10, no. 1, pp. 5-14, 2003.

[21]K. Buch and S. Harden, "The impact of a servicelearning project on student awareness of homelessness, civic attitudes, and stereotypes toward the
homeless.", Journal of Higher Education Outreach and Engagement, vol. 15, no. 3, pp. 45-61, 2011.

[22]D. Fudge, F. Burton, T. McClam and J. Diambra, "An Analysis of a Service-Learning Project: Students" Expectations, Concerns, and Reflections." Journal of Experiential Education, vol. 30, no. 3, pp. 236-249, 2008.

[23]M. Krebs, "Service-learning: Motivations for k-12 teachers." Doctorate, Graduate College of Bowling Green State University, 2006.

[24]D. Wittmer, "Business and community: Integrating service learning in graduate business education", Journal of Business Ethics, vol. 51, no. 4, pp. 359-371, 2004.

[25] J. Creswell, Educational Research: Planning, Conducting, and Evaluating Quantitative and
Qualitative Research, 2nd ed. Michigan: Merrill, 2005. 
Proc. of The Seventh Intl. Conf. on Advances in Social Science, Management and Human Behaviour - SMHB 2018.

Copyright (C) Institute of Research Engineers and Doctors, USA. All rights reserved.

ISBN: 978-1-63248-160-3 doi: 10.15224/978-1-63248-160-3-21

[26]E. Vlahos, "Service learning and community outreach in architecture curricula." 2001.

About Author (s):

\begin{tabular}{|c|}
\hline Image \\
\hline $\begin{array}{c}\text { [The study suggests that SL pedagogy } \\
\text { nurtures commitment in students towards } \\
\text { community involvement and at the same } \\
\text { time enhances students' learning } \\
\text { experience.] }\end{array}$ \\
\hline
\end{tabular}

